\title{
Martin Edmond
}

\section{Memory, voice, occasion}

A central curiosity of the Western tradition, rooted in Greek thought, is the habit of invoking the muse or muses at the inauguration of a work. Who were or are the muses? What do we know about them and how are we to understand them today? Homer speaks indiscriminately of the muse and the muses and doesn't name them; Hesiod says they are nine, naming all, though without giving them the specific attributes common only since the Renaissance, and is explicit about just one, Calliope, whose name means 'beauty of voice' (Skarsouli 2006: 212). The nine, he says, are the daughters of Zeus and Mnemosyne, or memory - one of those 'abstract ladies' (Kirk 1974: 118) of Greek thought.

The Greek mousa may be related to the verb mimnesko, to remind, to bring to, or put in, mind; which, in turn, can be derived from Proto-Indo-European men-, think. The crucial act inspired by the muses would seem to be that of remembering. Even the Greek word for truth, aletheia is said by some to mean not-forgetting; or, in another version, the enigmatic 'unconcealment of beings' (Güren 2005: 90).

If we leap a millennium and recall what historian and traveller Pausanias has to say we find a different, perhaps older, tradition. Pausanias, a Lydian who wrote in the second century AD when Roman emperors ruled most of the known the world, recounts in his Description of Greece many versions of muse worship from different parts of the country. In his account of the rites at Helicon he says that there were originally only three and they were the children of Uranus (the sky) and Gaia (the earth) (Pausanias c.143-161 AD: ix. 29). These three are: Mneme (memory), Aoide (voice) and Melete (occasion). He mentions that at Delphi also three muses were worshipped but they had different names: Nete, Mesi and Hypate, which are what three chords of that ancient instrument, the lyre, are called.

While mneme seems always to be memory, aoide may also be translated as song, and melete can mean both meditation and practice as well as occasion. Whichever way you look at them the three attributes are essential to any musical, poetic or theatrical act: you memorise, you practice, you perform. It has been said that together they form the complete picture of the preconditions of poetic art. With this rider: in cult practice, which seems to take us far away from modernity into the mysteries of the archaic occasions for art. Or perhaps not - if you read Homer it's clear that minstrels played and sang at feasts, when visitors were entertained or marriages made, or at funerals as the dead were interred with games and songs.

In an essay published in Oral Tradition Penelope Skarsouli quotes this passage from the Proem to Hesiod's Theogony:

Happy is he whom the Muses love: speech flows sweetly from his mouth. For though a man has sorrow and grief in his soul and lives in dread because his heart is distressed, yet when a 
singer, the servant of the Muses, chants the glorious deeds of men of old and the blessed gods who inhabit Olympus, at once he forgets his heaviness and remembers not his sorrows at all; the gifts of the goddesses soon turn him away from these. (Skarsouli 2006: 214-5)

Then she points out the conjunction of memory and forgetting: 'whoever hears the Muses, the daughters of Mnemosyne, no longer remembers his own ills' (2006: 215). There is an apparent ambiguity here: it could be the singer who forgets his or her miseries in the song; or the singing that allows the audience to forget. In the old days it was certainly thought to be the latter; but now we might be tempted to allow both possibilities.

Skarsouli also mentions that in some parts of Greece the muses were known as the Memories and it was often said that their closest companion was Hypnos or Sleep, whose three sons by Nyx or Night, Phobetor, Phantasos and Morpheus, are the bringers of dreams (Hesiod 1914: II, 212). Phobetor conjured animals and nightmares and gives us our word phobia; Phantasos, whose visions were delusive and made out of inanimate things, is the origin of our word fantasy; and from Morpheus, who gives human shape to our dreams, we have derived, among other things, the word for morphine, a drug that eases pain.

In her paper Skarsouli is teasing out a particular strain in Greek thought, that which identifies Calliope as the chief of the nine muses and puts her in a particular relation with 'worshipful princes' (2006: 211). Her thesis is that those in power need both the true thought and the eloquent voice granted by the muse in order to act righteously: that is, to arrive at a just solution and then to persuade the people of its rightness. This venerable dimension to inspiration is still sometimes evoked when we recall the phrase, 'speaking truth to power'.

Our legal system is based on precedent and this was so in Greece in preliterate times as well, where memory was understood as an aid to dispensing justice; there were in some Greek cities judicial officials called mnemones or rememberers whose precise function was to recall and cite precedents. There was another class, the hieromnemones or sacred rememberers with a particular duty to recall religious history. An analogous function perhaps is that of the servant required to stand next to a king or emperor and remind him that he is, after all, a mortal man. This role too has persisted, it is probably the source of the character of the Jester or Fool who is allowed to speak a truth that others might face execution for uttering. Writers today often aspire to this role, without much hope, at least in the West, either of being listened to or of execution.

Calliope is not simply first among the muses, she is also the mother, perhaps by the Thracian King Oeagrus, of Orpheus. I don't wish to rehearse the entirety of the Orpheus story here, only its later, less well known, component. After losing Eurydice forever, Orpheus wandered mourning over the earth; Ovid says he refused the love of women and makes him the father of pederasty; it is for this, he writes, and for condemning their promiscuity, that the Maenads tore his body limb from limb (Ovid 1955: 246). In another version they destroy him because he can't or won't sing joyful songs for their dances. A third reason given is that Orpheus insisted on worshiping one god only, the sun, Apollo. His turning away from the orgiastic cult of Dionysus in favour of a male-centred Apollonianism was for Robert Graves the cause of his dismemberment (1969: 112). 
His decapitated head, still singing, floated down the Hebrus to the Aegean Sea, later coming ashore at Lesbos, where it continued to prophesy from a cave sacred to Dionysus until the oracle was silenced by a jealous Apollo. Lesbos was considered the home of lyric poetry and Sappho, whose island it was, is sometimes called the tenth muse. Meanwhile the nine muses gathered up the rest of Orpheus' body and buried it at Helicon at the foot of Olympus where the nightingales still sing more sweetly than anywhere else. His golden lyre also drifted to Lesbos where it was placed in a shrine dedicated to Apollo before being set up among the stars as the constellation Lyra.

There are curious contradictions here: the great exemplar of romantic love become a spurner of women; the supreme poet of nature turned monotheist; the bequeathing of his prophetic head to Dionysus while his lyre returns to Apollo, the god who gave it to him in the first place. However it is certainly a mistake to think that among the many extant versions of this story there is one that is definitive. Over a thousand years of antiquity, and two thousand years since, it has been told and retold in what amounts to a practical infinity of versions ... and yet we persist in our belief that across all versions there is something incontrovertible, a substratum of truth; just as, when we look at the many accounts of who the muses were, we continue to think that they are, or could be, one.

This may be because, in both stories, we find a narrative that encloses a mystery. It may even be the case that it is this mystery, precisely, that gives us the notion of the incontrovertible, which would then be something that both is and is not; or rather, something that is but is not to be spoken. No-one who reads, hears, or sees enacted the story of Orpheus is immune from the desire that he not look back to see his beloved walking out of hell behind him; equally, no-one can fail to imagine that he will not just want to look back, but that he will do so. It is as inconceivable as the thought that Eve will not taste the fruit of the Tree of Knowledge offered her by the snake.

In somewhat the same way, the irrationality of supposing that, when we write or paint or compose or otherwise make art - and even perhaps dispense justice - we do so by entertaining within us a spirit that is somehow both other to, and kin with, our deepest selves, alien and yet not alien, at once us and not us, has survived all attempts to banish or ridicule it. There are too many testimonies by people who say they have felt taken over, possessed or made into a vessel by some power, for us entirely to dismiss either the experience or the possibility. This does not mean that it is not a human capacity we are speaking of - just that it is one that is peculiarly resistant to rational explanation.

In voodoo dancing, a god, as the Greeks would say, enters the dancer; which god - or loa - will be known by the steps the dancer takes. Whether it be Damballah, Ezili, Ogu, Agwe, Legba or another can thus be recognised by others and has significance both for them and for the individual dancer. This is not the only example of a dance tradition where there is a definite relationship between the steps a dancer takes and the spirit, loa or god who has entered them. Even on today's dance floors you can see how a different beat will call forth a different step and how some steps seem perfectly to express some beats. Every riddim seems to have its own dance, its own set of moves.

This relationship is best expressed for me by a silent thing, a photograph. It is called Dancers, New York, 1956 and was taken by jazz photographer Roy DeCarava at the Manor Social Club, now demolished, that stood at 110th Street and Madison Avenue in Harlem. In dim light on the wide otherwise 
empty wooden floor two men, seen only in silhouette, are dancing with each other. The one closest to the camera has his back to us. He is a big bald head with a single highlight on the right of the dome; an oblong jacket tilted by the movement of his shoulders to a trapezoid; one arm so hung down it almost drags its knuckles along the floor, the other raised up, with the fingers extended and flexed; two shapeless almost bulbous legs disappearing into the shadowy floor.

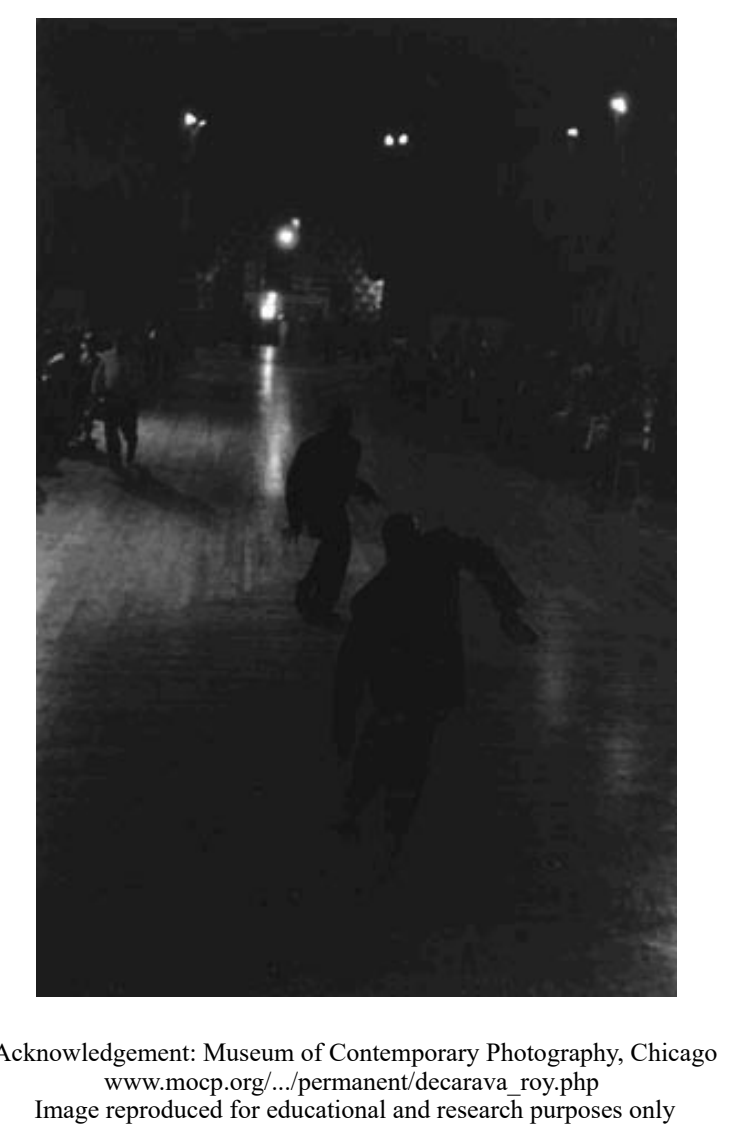

The other, facing us, is his echo or mirror. A slighter man, perhaps shorter, he too is elegantly poised about the oblong of his jacket, his knees bent, together, one foot, the right, raised from the floor; his right arm, like his partner's left, hanging down with all the fingers spread, his left bent ninety degrees at the elbow, the hand flat, held out, the fingers arched. A waiter in a white shirt with a tray of drinks moves up the left hand edge of the dance floor and, at either side, we see the shapes of people sitting on chairs at tables. Behind, through a mosque or pyramid shaped arch, perhaps the entrance to the hall, a bright flare of light comes in along the floor but does not quite reach the second dancer; while in the roof seven white lamps glow but do not illuminate the vast, dark space.

No faces can be seen in the dimness, nor much other detail and certainly no musicians or any other source of music; they might be dancing to a gramophone record. Nevertheless, and here is the paradox, the photograph sings. Somehow, despite or because of the stillness of the silhouettes, those bodies frozen in motion, you feel yourself to be inside the actual moment of the music to which they are making these particular moves. This paradox, which I cannot give any better account of, is perfectly expressed in the title of the book in which the photograph appears: The Sound I Saw (DeCarava 1983: 37).

You don't have to subscribe to any particular religion or other form of spirituality to dance to music, even though music and dance do have a long history of entanglement with the sacred. What's interesting is that we can still act as if possessed, we can still actually become possessed, even when we 
don't believe in possession as such. There is some intrinsic human relation to beats, to music, to song and we best express that relation in movement, in dance. This seems to be true across all ages, all cultures, all times. Even very small children will move to music; even the aged and infirm; even the clodhopping or tone deaf will try or want to try.

To dance we need those three original muses: memory, voice, occasion, however paradoxical or hidden their manifestation may be. Memory, when it comes to dance, may not inhere in the mind at all but in the body or perhaps somewhere else entirely like the soul; voice will be there in the song or the music to which we dance, even if that be, as it sometimes is, an unheard melody - which Keats reminds us are sweeter, 'piping to the spirit ditties of no tone' (1967: 294). He was remembering dancers on a Grecian urn when he wrote that. Occasion, too, is various, you can as easily dance to a song on the radio in your car, to the stereo in your sitting room, at a vast outdoor concert or in a club or pub or bar somewhere. You can even dance in your mind.

And, as every dancer knows, just as you must remember in order to dance, the dance itself will help you to forget. This central paradox - memory (mneme) and forgetting (lethe) entwined together - is there from the beginning, right back in Hesiod where it is said that the muses make us forget our sorrows by remembering, not joy as such, but the great deeds of heroes and the gods (Skarsouli 2006: 214). Those are not our subject any more, we who write, but it is still the case that writing is intimately involved with memory and forgetting. I formulated this once as follows: 'We remember in order to write but we write to forget' (Edmond 2008: 15). Reading, too, can be an act of remembrance that allows you to forget. To become, in other words, lost in story, enchanted, possessed, perhaps even changed.

Yet the relationship of writing to memory is not simple, for it is now clear that all acts of memory are to some extent also acts of story telling; the idea that there is some objective truth that memory - including written memory - can give us access to is simply no longer tenable. When we write we are both remembering and forgetting, choosing those details that most impress or obsess us and eliding others that do not signify or that for some reason we think inappropriate or just plain wrong. This process is better understood in fiction writing than it is in the vast and various field we call non-fiction.

Somehow, in non-fiction writing, the conviction that objective truth is available to us through recall and research persists, whereas in fiction most of us are comfortable with the notion that a kind of meta-truth can emerge from an artful confection of narrative and descriptive sources, including inventions, that do not need to be specified, instead relying for their impact upon their imaginative coherence. My own feeling is that the art of the real differs from the art of fiction not in kind but in degree; that our (relatively recent)

distinction between the two categories is artificial, made not because one tells the truth and the other does not but because they follow different methodologies. That is, one relies explicitly upon invention while the other recovers what we think of as fact.

These methodologies may not be as dissimilar as we like to think: if the muses are also the memories, or the daughters of memory, then they are just as involved in the recall necessary to construct a work of non-fiction as they are when we write fiction. Further, in any of the kinds of writing that are conventionally termed non-fiction - whether by that we mean biography, memoir, an account of a concert or a sports match, the writing up of a scientific experiment, the progress of a voyage, a confession, a meditation or a dream - there will inevitably be a proportion of willed or unwilled 
forgetting, if only because the multifarious nature of the world and of the mind requires us to select and in selecting we both remember and forget.

In this sense, invocation of a muse or muses and the consequent possession might be understood as a way of entering the zone in which the capacity, the ability to tell a story properly is attained. It may be that in certain states of mind we do not so much remember as intuit those aspects of circumstance, character, action, description and the rest that will make good writing possible. The muse or muses would them symbolize the swiftness, the accuracy, the power and the beauty that, in a seemingly unwilled way, sometimes manifest themselves in us and allow us to write effortlessly what we might otherwise labour over or even botch. And if this is so, it applies to the art of the real as much as it does to fiction writing.

But there is an even more obvious sense in which the muses are present in any act of writing - even the writing of this essay, which I began by searching in those great repositories of cultural memory, books; then I wrote down my thoughts on these matters in a manner as coherent, indeed eloquent as I was able, trying to find my own voice, speaking my sentences silently to myself or aloud into the air. Finally the occasion for this meditation is surely, like Janus, two-faced: one is that of my own perplexity, attempting understanding of a very old tradition of which I am, howsoever insignificant, still a part; while the other is your face, looking perhaps with a similar perplexity, perhaps with something more like illumination, at the trail of words I've left here.

And if there is an illumination to be had amidst the perplexity, this may be what it is: I'm not possessed by a god or goddess or any other alien or familiar spirit, I'm not speaking in the precinct of a temple, I'm not intoxicated or deranged, my words are not prophetic or otherwise revelatory of the sacred; and yet, mysteriously, even here, even now, in this most prosaic of circumstances, a man sitting at a computer in a small flat in a modern city, the ancient conditions of vatic speech continue to manifest: memory, voice, occasion.

\section{List of works cited}

DeCarava, Roy 1983 The sound I saw: the jazz photographs of Roy deCarava, New York: The Studio Museum of Harlem return to text

Edmond, Martin 2008 The evolution of mirrors, Rockhampton: Otoliths return to text

Graves, Robert 1969 The Greek myths 1 \& 2, Harmondsworth: Penguin return to text

Güren, Ferit 2005 Madness and death in philosophy, New York: SUNY Press return to text

Hesiod 1914 Theogony, London: William Heinemann return to text

Keats, John 1967 'Ode on a grecian urn', Complete poetry and selected prose of John Keats, New York: Random House return to text

Kirk, G.S. 1974 The nature of Greek myths, Harmondsworth: Penguin return to text

Ovid 1955 Metamorphoses (trans Mary M. Innes), Harmondsworth: Penguin return to text

Pausanias c.143-161 AD Description of Greece (trans W.H.S Jones), Internet ancient history sourcebook http://www.fordham.edu/halsall/ancient/pausanias-bk1.html (accessed 14 June 2007) return to text

Skarsouli, Penelope 2006 'Calliope, a muse apart: some remarks on the tradition of memory as a vehicle of oral justice', Oral tradition 21.1 (March), 
http://muse.jhu.edu/journals/oral_tradition/toc/ort21.1.html (accessed 10 June 2007) return to text

Martin Edmond is a freelance writer living in Sydney.

TEXT Special Issue No 5 The Art of the Real

April 2009

http://www.textjournal.com.au

Editors: Keri Glastonbury and Ros Smith

General Editors: Nigel Krauth \& Jen Webb

Text@griffith.edu.au 